\title{
Informasi Praktis Destinasi Wisata Berbasis Chse Untuk Pengembangan Potensi Wisata Desa Mangunan
}

\author{
Adriano Bandi Susteyo Martins ${ }^{1}$, Advent Pateh ${ }^{2}$, Alfian Bayu Putra Darma Yunantoro ${ }^{3}$, Edwin Juan Sugianto ${ }^{4}$, Jessica Kathy
}

Adelea Br Ginting ${ }^{5}$, Laura Jessica Griselda ${ }^{6}$, Lavinia Jacinda ${ }^{7}$, Nataniel Eko Irianto ${ }^{8}$, Noval Izra Kadavhi ${ }^{9}$, Rosadema

Valenthalia Anggraeni ${ }^{10}$, Dewi Krisna Hardjanti ${ }^{11}$

Universitas Atma Jaya Yogyakarta

Jl. Babarsari No. 44, Janti, Caturtunggal, Kec. Depok, Kabupaten Sleman, Daerah Istimewa Yogyakarta

Email: dewi.hardjanti@uajy.ac.id ${ }^{11}$

Received: December 1, 2021 ; Revised: -; Accepted for Publication March 8, 2021; Published: March 8, 2022

\begin{abstract}
KKN are community service activities in certain areas that are carried out in groups. KKN 80 UAJY carries out Society 5.0 type, which is carried out without any KKN activities which are carried out directly in the designated area and through online. Group 6 got a placement location in Mangunan Village, Dlingo District, Bantul Regency, Yogyakarta Special Region. The work program will be carried out by the group is village potential and making pocket book about tourism in Mangunan Village. This Mangunan Village potential work program provides information on CHSE-based tourist guides imposed by the government. Another work program it's make a pocket book about tourism in Mangunan Village. It is hoped that the work program made by the group can be useful for the community for village progress.
\end{abstract}

Keywords- KKN, Mangunan Village, Work Program, Village Potential, CHSE.

\begin{abstract}
Abstrak - Kuliah Kerja Nyata adalah merupakan kegiatan pengabdian kepada masyarakat di daerah tertentu yang dilaksanakan secara kelompok. KKN 80 UAJY mengusung KKN jenis Society 5.0 yang dilakukan tanpa adanya kegiatan KKN yang dilakukan secara langsung didaerah yang ditentukan dan melalui daing. Kelompok 06 mendapatkan lokasi penempatan di Desa Mangunan, Kecamatan Dlingo, Kabupaten Bantul, Daerah Istimewa Yogyakarta. Program kerja yang akan dilakukan oleh kelompok adalah potensi desa dan membuat buku saku tentang wisata-wisata yang ada di Desa Mangunan. Program kerja potensi Desa Mangunan ini dengan memberikan informasi panduan wisata berbasis CHSE yang diberlakukan oleh pemerintah. Program kerja lainnya yang dibuat adalah membuat buku saku tentang wisata-wisata yang ada di Desa Mangunan. Harapannya program kerja yang dibuat oleh kelompok dapat berguna untuk masyarakat untuk kemajuan desa.
\end{abstract}

Kata Kunci - Kuliah Kerja Nyata, Desa Mangunan, Program Kerja, Potensi Desa, CHSE.

\section{PENDAHULUAN}

Desa Mangunan merupakan sebuah desa yang terdapat di Kecamatan Dlingo, Kabupaten Bantul, Daerah Istimewa Yogyakarta. Desa Mangunan memiliki 6 dusun atau pedukuhan antara lain Pedukuhan Cempuk, Pedukuhan Mangunan, Pedukuhan Sukorame, Pedukuhan Lemahbang, Pedukuhan Kediwung, dan Pedukuhan Kanigoro.

Desa Manguan memiliki total luas area $9,52 \mathrm{~km}^{2}$ dengan berlokasi pada Bujur $110^{\circ} 25^{\prime} 08^{\prime \prime}$ dengan Lintang $07^{\circ} 55^{\prime} 54^{\prime}$ '. Desa Mangunan memiliki jarak $14 \mathrm{~km}$ dari Kota Yogyakarta. Desa Mangunan merupakan desa yang terkenal dengan sebutan desa wisata, dimana daerah ini memiliki cukup banyak wisata alam. Wisata alam yang terdapat di desa Mangunan antara lain Jurang Tembelan, Pohon Pinus, Wisata Mangunan dan Gardu Pandang Mangunan, dll.

Adanya bermacam wisata alam yang dimiliki desa Mangunan memberi ketertarikan untuk membuat desa ini menjadi berkembang agar lebih dikenal oleh masyarakat. Dengan melihat potensi dibidang wisata yang dimiliki desa ini, kelompok ingin membuat program terkait "Informasi Praktis Destinasi Wisata di Desa Mangunan".

Program ini akan dibuat dalam bentuk buku saku yang berisi rmengenai infromasi praktis terkait destinasi wisata yang berada di desa Mangunan. Buku saku ini juga bertujuan untuk memberikan paduan destinasi wisata alam untuk wisatawan yang datang ke desa Mangunan.

Dengan dilaksanakannya program ini diharapkan untuk mempermudah para wistawan dan serentak juga dapat meningkatkan ketertarikan wisatawan untuk datang berwisata di wisata desa Mangunan. Hal ini juga diharapkan agar masyarakat dapat memanfaatkan untuk menambah pendapatan masyarakat daerah tersebut. Selain itu program ini juga diharapkan masyarakat juga tetap bisa menjaga, melestarikan dan memiliki pengetahuan mengenai berbagai destinasi wisata alam yang ada di Desa Mangunan. 


\section{Metode PENGABdian}

Oleh karena UAJY menerapkan konsep KKN Society 5.0 yang berarti KKN 80 dilaksanakan secara daring tanpa penerjunan langsung dilapangan di desa Mangunan, maka bahan data yang digunakan oleh Kelompok $06 \mathrm{KKN} 80$ UAJY dalam penelitian ini adalah data sekunder yang bersumberdari data statistik lembaga resmi, buku, jurnal, peraturan perundangundangan, dan internet melalui website resmi pemerintahan, artikel serta berbagai dokumen terkait lainnya tentang desa Mangunan.

Kumpulan data tersebut dengan teknik observasi kemudian oleh kelompok diolah secara deskriptif. Terhadap kumpulan data penelitian tersebut kemudian secara kualitatif dianalisis dengan model Miles dan Huberman melalui tiga aktivitas yakni, "data display, reduction, dan conclusion drawing atau verification" [1].

Pada bagian akhir, oleh kelompok secara induktif ditarik kesimpulan berupa temuan potensi desa yang ada serta usulan berupa program perlunya suatu panduan yang bersifat informatif praktis bagi pengelolaan destinasi wisata di desa Mangunan.

\section{HASIL DAN PEMBAHAAN}

\section{Tinjauan tentang Informasi}

Informasi diartikan suatu pernyataan, keterangan, tanda, dan suatu gagasan yang berisi terkait nilai dan pesan berupa data, fakta ataupun penjelasan yang dapat diketahui, didengarkan, dan diperhatikan yang diberikan dalam bermacam format sesuai adanya peningkatan teknologi informasi dan komunikasi baik elektronik ataupun bukan elektronik [2]. Teknologi Informasi juga dipahami sebagai sebuah teknik yang bertujuan mengumpulkan, mempersiapkan, menyimpannya, memprosesnya, mengumumkannya, menganalisisnya, dan menebarkan informasi [3]. Menurut definisi tersebut, maka disimpulkan jika panduan informasi adalah sekumpulan petunjuk sebagai pernyataan, gagasan, keterangan, dan tanda yang memiliki nilai, dan pesan berupa data, fakta ataupun penjelasannya yang dapat diketahui, didengarkan, dan diperhatikan yang diberikan dalam bermacam dan format sesuai adanya peningkatan teknologi informasi dan komunikasi baik elektronik maupun bukan elektronik yang tergabung menjadi acuan atau instruksi dalam melaksanakan suatu hal dengan terarah, sistematis, tepat berdasarkan petunjuk, dan mudah untuk pencapaian tujuan.

\section{Dasar Hukum tentang Informasi}

Informasi adalah bagian dari kebutuhan yang pokok bagi setiap orang untuk pengembangan pribadi dan lingkungan sosialnya dan juga merupakan hal yang penting penting untuk ketahanan nasional [2]. Oleh sebab itu, pada instrumen hukum nasional, hak atas informasi diletakan pada posisi yang cukup tinggi. Hak untuk tahu adalah hak konstitusional bagu setiap warga negara Indonesia.

Hak pada hakikatnya merupakan hubungan hukum antara subjek hukum dengan objek hukum atau subjek hukum dengan subjek hukum lain yang dilindungi oleh hukum dan menimbulkan kewajiban [4]. Hak ini ada di dalam Pasal 28 F UUD 1945 yang meyatakan bahwa setiap orang berhak berkomunikasi dan memperoleh informasi [5]. Bahkan, hak untuk tahu merupakan bagian dari hak asasi manusia yang perlu dipenuhi oleh negara dikarenakan jadi hak yang melekat bagi setiap warga negara. Maka dari itu, mendapatkan informasi sebagai hak asasi manusia merupakan suatu wujud dari kehidupan sebagai bangsa dan negara yang demokratis [6].

Berdasarkan pengertian tersebut, maka hak atas informasi diklasifikasikan sebagai hak konstitusional yang menuntut kewajiban negara dalam pemenuhannya. Hak atas informasi sejatinya menjadi pembuka jalan bagi terjaminnya pelaksanaan hak-hak asasi lainnya, seperti hak atas pendidikan, hak untuk hidup sejahtera, hak untuk hidup aman, dan hak warga negara lainnya. Melalui pemenuhan hak itu, diharapkan akan dapat memastikan peningkatan kualitas hidup warga negara.

\section{Tinjauan tentang Panduan Wisata Berbasis CHSE}

CHSE adalah "Cleanliness, Health, Safety and Environmental Sustainability atau Pelaksanaan Kebersihan, Kesehatan, Keselamatan, dan Kelestarian Lingkungan yang merupakan panduan operasional untuk sektor Pariwisata dari Keputusan Menteri Kesehatan Nomor HK.01.07/Menkes/ 382/2020 tentang Protokol Kesehatan bagi Masyarakat di Tempat dan Fasilitas Umum dalam Rangka Pencegahan dan Pengendalian Coronavirus Disease 2019 (Covid-19)'”[7].

CHSE ini merupakan program Kemenparekraf berupa penerapan protokol kesehatan yang ujuannya adalah untuk meningkatkan upaya pencegahan dan pengendalian Covid-19 bagi masyarakat di tempat dan fasilitas umum dalam rangka mencegah terjadinya episenter atau kluster baru selama masa pandemi [8].

Atas adanya CHSE ini, diperlukan penyebaran informasi yang sistematis dan komprehensif agar masyarakat pelaku wisata menyadari dan mampu mengimplementasikan prinsip-prinsip CHSE yang 
sesuai dengan kebutuhan wisatawan di masa pandemi seperti saat ini [9].

\section{Tinjauan tentang Kepariwisataan}

Kegiatan pariwisata adalah suatu kegiatan yang secara langsung menyentuh dan melibatkan masyarakat, sehingga membawa berbagai dampak terhadap masyarakat setempat [10]. Secara normatif, tentang kepariwisataan didefinisikan sebagai berikut [11]:

1. Wisata adalah kegiatan perjalanan yang dilakukan oleh seseorang atau sekelompok orang dengan mengunjungi tempat tertentu untuk tujuan rekreasi, pengembangan pribadi, atau mempelajari keunikan daya tarik wisata yang dikunjungi dalam jangka waktu sementara.

2. Wisatawan adalah orang yang melakukan wisata.

3. Pariwisata adalah berbagai macam kegiatan wisata dan didukung berbagai fasilitas serta layanan yang disediakan oleh masyarakat, pengusaha, Pemerintah, dan Pemerintah Daerah.

4. Kepariwisataan adalah keseluruhan kegiatan yang terkait dengan pariwisata dan bersifat multidimensi serta multidisiplin yang muncul sebagai wujud kebutuhan setiap orang dan negara serta interaksi antara wisatawan dan masyarakat setempat, sesama wisatawan, Pemerintah, Pemerintah Daerah, dan pengusaha.

\section{Hasil Potensi Desa}

Desa Mangunan mempunyai luas wilayah 952,3715 ha. Desa ini memiliki banyak wisata alam yang bemacam-macam yang menjadi daya tarik bagi para wisatawan. Sehingga penelitian ini memberikan ide untuk pengembangan wisata di Desa Mangunan.

E-book Potensi Desa Mangunan membahas mengenai profil desa, potensi desa, pariwisata, objek wisata, dan panduan CHSE. Pada bagian ini, kelompok memberi pemetaan terhadap potensi wisata di desa Mangunan. Potensi yang ada pada Desa Mangunan ini sebenarnya banyak, entah dari segi pertanian atau dari segi hortikultura, segi agribisnis, segi budaya, serta segi argo wisatanya. Akan tetapi potensi yang paling menonjol adalah dari segi pariwisatanya, dikarenakan banyaknya ditemukan tempat wisata di Desa Mangunan.

\section{E-Book Potensi Desa}
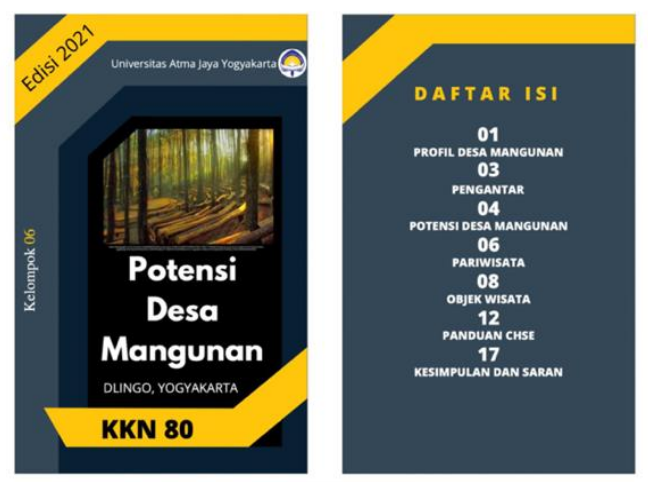

Gambar 1: E-book Potensi Desa

Sumber: Analisis Kelompok, 2021

Sebagai mahasiswa/i yang tergabung dalam program KKN, kami dari kelompok KKN 06 UAJY memiliki ide untuk menambahkan program yang berupa panduan berbasis CHSE. Panduan CHSE ini diolah dengan mempertimbangkan beberapa aspek yang ada pada pariwisata agar dapat dilaksanakan sebagaimana mestinya, isi dari panduan ini berisi seperti panduan pencegahan penyebaran covid-19, pembatasan pemakaian beberapa barang yang mungkin merugikan atau membahayakan, dan beberapa panduan lainnya.

\section{Hasil Buku Saku}

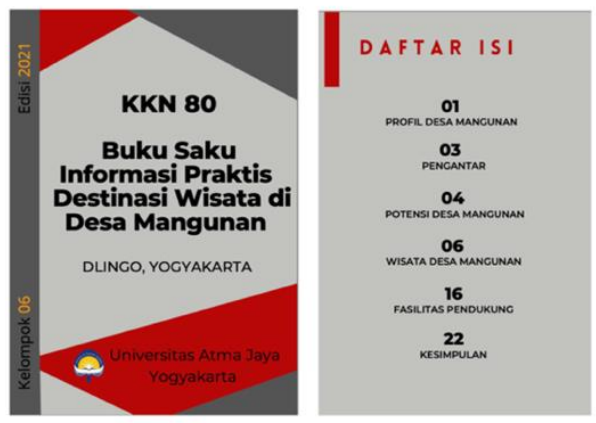

Gambar 2: Buku Saku

Sumber: Analisis Kelompok, 2021

E-book Buku Saku Mangunan membahas mengenai profil desa, potensi desa, wisata desa, fasilitas pendukung dan kesimpulan desa Mangunan. Oleh kelompok, informasi sederhana melalui buku saku yang kami susun ini diharapkan mampu dipergunakan dengan semestinya demi kepentingan bersama. Dengan adanya informasi praktis melalui buku saku ini diharapkan mampu membantu perkembangan Desa Mangunan untuk bisa lebih dikenal dan menjadi daerah prioritas tempat wisata di Provinsi Daerah Istimewa Yogyakarta. Penjabaran potensi wisata Desa 
Mangunan di atas bertujuan untuk memberikan kemudahan kepada para wisatawan yang hadir di Desa Mangunan untuk dapat dengan mudah berkeliling menikmati kekayaan alam yang luar biasa. Panduan sederhana tersebut diharapkan bisa memberikan manfaat bagi banyak orang terutama bagi Desa Mangunan.

\section{Hasil video potensi Desa}

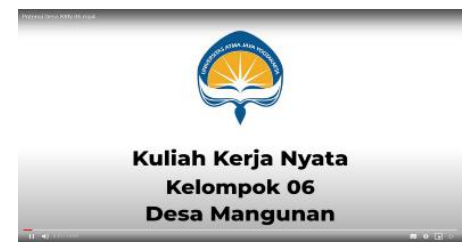

Gambar 3: Video Sumber: Analisis Kelompok, 2021

Video Potensi Desa disusun oleh kelompok 6 dengan durasi sekitar 10.55 menit. Video Potensi desa ini berisikan tentang awal topografi desa, jumlah penduduk, makanan khas, kesenian, mata pencaharian, kerajinan, pertanian dan peternakan.

Tabel 1. Demografi Masyarakat Desa Mangunan

\begin{tabular}{|l|l|l|}
\hline No & Kelompok Umur & Jumlah \\
\hline 1 & $0-4$ Tahun & 341 \\
\hline 2 & 5-14 Tahun & 938 \\
\hline 3 & 15-64 Tahun & 3199 \\
\hline 4 & 60-65 Tahun & 869 \\
\hline 5 & $>65$ Tahun & 619 \\
\hline
\end{tabular}

Sumber: https://bps.go.id, tanggal diakses 25

November 2021

Tabel 2. Demografi Masyarakat Desa Mangunan

\begin{tabular}{|l|l|l|}
\hline No & Jenis Kelamin & Jumlah \\
\hline 1 & Laki-laki & 2356 \\
\hline 2 & Perempuan & 2430 \\
\hline Total & & 4786 \\
\hline
\end{tabular}

Sumber: https://mangunan.bantulkab.go.id/first diakses 25 November 2021

\section{UCAPAN TERIMAKASIH}

Ucapan terimakasih juga kepada semua pihak yang ikut berkontribusi dalam pengerjaan tugas kelompok sehingga dapat terselesaikan.

\section{DAFTAR PUSTAKA}

[1] A. Supratiknya, Metode penelitian kuantitatif dan psikologi. Bandung: Alfabeta, 2015.

[2] Jogloabang.com, "UU 14 Tahun 2008 Tentang Keterbukaan Informasi Publik." 2019, [Online]. Available: https://www.jogloabang.com/pustaka/uu-142008-keterbukaan-informasi-publik.

[3] UU ITE, "Undang-Undang Republik Indonesia Nomor 11 Tahun 2008 Tentang Informasi Dan Transaksi Elektronik," Cell, vol. 151, no. 4. pp. 1-46, 2008, [Online]. Available:

http://dx.doi.org/10.1016/j.biochi.2015.03.02 5\%0Ahttp://dx.doi.org/10.1038/nature10402 \%0Ahttp://dx.doi.org/10.1038/nature21059\% 0Ahttp://journal.stainkudus.ac.id/index.php/e quilibrium/article/view/1268/1127\%0Ahttp:// dx.doi.org/10.1038/nrmicro2577\%0Ahttp://.

[4] S. Mertokusumo, Mengenal Hukum Suatu Pengantar, Liberty, Yogyakarta. Yogyakarta: Cahaya Atma Pustaka, 2013.

[5] Presiden RI, "Perubahan Kedua UndangUndang Dasar Negara Republik Indonesia Tahun 1945," Dewan Perwakilan Rakyat Republik Indonesia. pp. 1-6, 2000, [Online]. Available:

http://www.perpustakaan.depkeu.go.id/FOLD ERDOKUMEN/UUD

1945.pdf\%5Cnhttp://www.pta-

makassarkota.go.id/peraturan_perundangan/ UUD/UUD AMANDEMEN 2 1945.pdf.

[6] Kementerian Hukum dan HAM RI, "UndangUndang Republik Indonesia Nomor 39 Tahun 1999 Tentang Hak Asasi Manusia," UndangUndang Republik Indonesia Nomor 39 Thn 1999 tentang Hak Asasi Manusia, no. 39. p. 43, 1999.

[7] K. P. dan E. Kreatif, "Panduan Pelaksanaan Kebersihan, Kesehatan, Keselamatan, dan Kelestarian Lingkungan di Daya Tarik Wisata," vol. Edisi Agus, p. 72, 2020.

[8] I. M. W. Candranegara, I. W. Mirta, and K. A. F. Putra, "Implementasi Program 'We Love Bali' Berbasis CHSE (Clean, Health, Safety, Environment) dalam Pemulihan Pariwisata Bali," J. Contemp. Public Adm., vol. 1, no. 1, pp. 27-32, 2021, doi: 10.22225/jcpa.1.1.3308.27-32. 
[9] A. Denny, Liyushiana, J. F. A. Sinaga, Jekson, and I. Wulandani, "Pelatihan Tata Kelola Pariwisata Dengan Pendekatan Chse Bagi Pelaku Perhotelan Di Kota Medan," Kumawula: Jurnal Pengabdian Kepada Masyarakat, vol. 4, no. 2. pp. 292-299, 2021, doi: 10.24198/kumawula.v4i2.32624.

[10] I. K. Suwena and I. G. N. Widyatmaja, "Pengetahuan Dasar Ilmu Pariwisata," 2010.

[11] Kementerian Pariwisata, "Peraturan Menteri Pariwisata Republik Indonesia Nomor 14 Tahun 2016 tentang Pedoman Destinasi Pariwisata Berkelanjutan," Www.Kemenpar.Go.Id/Post/PeraturanMenteri-Pariwisata-Nomor-14-Tahun-2016., no. Peraturan Menteri Pariwisata. pp. 1-64, 2016, [Online]. Available: www.kemenpar.go.id/post/peraturan-menteripariwisata-nomor-14-tahun-2016.

\section{PENULIS}

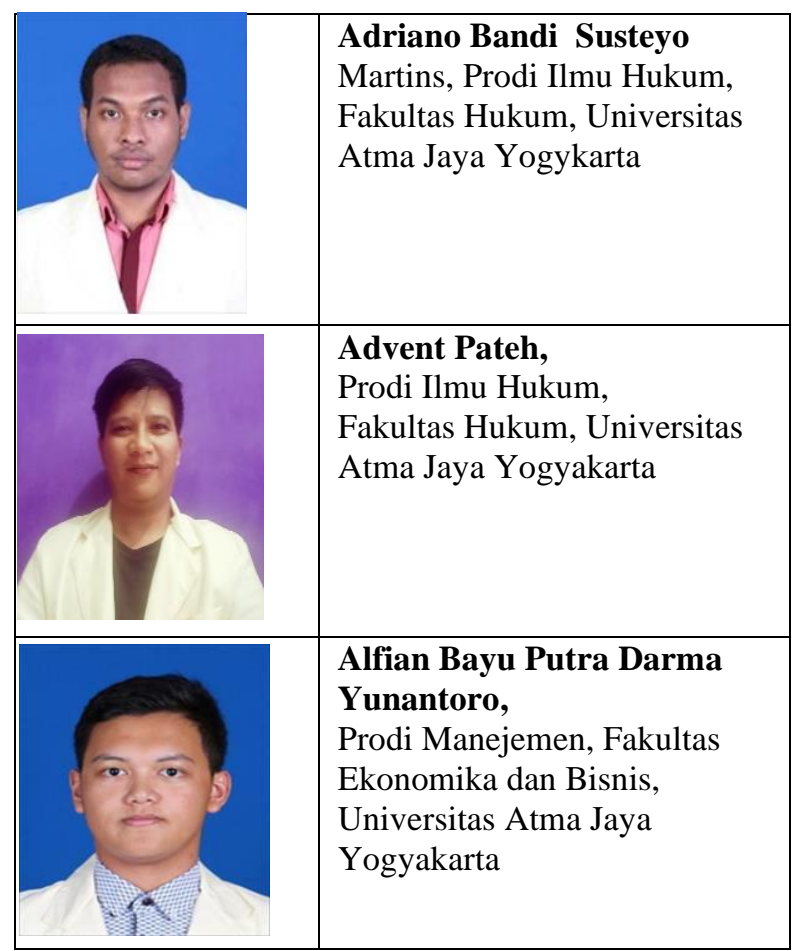

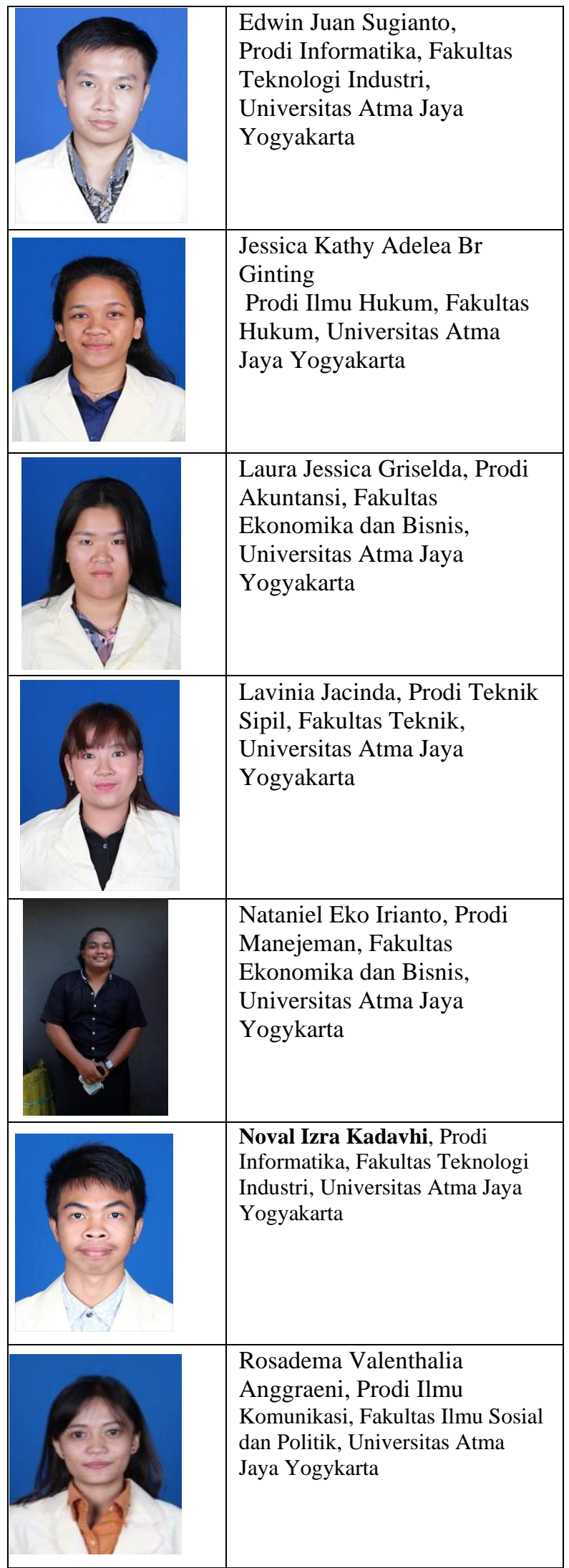


Jurnal Atma Inovasia (JAI)

p-ISSN: 2775-9385

Vol. 2, No. 2, Maret 2022

e-ISSN: 2775-9113

Informasi Praktis Destinasi Wisata Berbasis Chse Untuk Pengembangan Potensi Wisata Desa Mangunan

\begin{tabular}{|l|l|}
\hline & $\begin{array}{l}\text { Dewi Krisna } \\
\text { Hardjanti,S.H.,M.H., } \\
\text { Dosen Prodi Ilmu Hukum, } \\
\text { Fakultas Hukum, Universitas } \\
\text { Atma Jaya Yogykarta }\end{array}$ \\
\hline
\end{tabular}

